\title{
Epidemiological aspects of HCV infection in non-injecting drug users in the Brazilian state of Pará, eastern Amazon
}

Aldemir B Oliveira-Filho ${ }^{1,2^{*}}$, Leila Sawada ${ }^{3}$, Laine C Pinto ${ }^{4}$, Daiane Locks ${ }^{4}$, Santana L Bahia ${ }^{4}$, Jairo A A Castro ${ }^{2,5}$, Renata B Hermes ${ }^{2,4}$, Igor Brasil-Costa ${ }^{4,5}$, Carlos E M Amaral ${ }^{2,4}$ and José Alexandre R Lemos ${ }^{2,4}$

\begin{abstract}
Background: Currently, sharing of drug paraphernalia is the main form of HCV transmission worldwide. In South America, consistent findings indicate that shared sniffing equipment is an important factor in the spread of HCV among non-injecting drug users. Epidemiological data on the status of HCV infection in illicit drug users in the Amazon region are scarce, although reports of clinical cases of hepatitis or pathologies associated with HCV infection in other population groups are numerous. Thereby, this study investigated the prevalence, genotype frequency, and epidemiological factors associated with HCV infection in non-injecting drug users in the state of Pará, eastern Amazon.
\end{abstract}

Results: During 2008-2011, 300 non-injecting drug users attending drug-treatment centers participated in this study. Most non-injecting drug users were male (63.7\%). The mean age was 32.5 years. The non-injecting drugs most consumed were: cannabis (15.6\%), cocaine paste (21.3\%), and oxi cocaine (25.7\%). Tobacco (60.9\%) and alcohol (79.4\%) were also commonly consumed. One hundred six (35.1\%; Cl 95\%: 29.8 - 41.1) non-injecting drug users presented anti-HCV antibodies by EIA. The HCV-RNA prevalence was 28.0\% (95\% Cl: 20.6 - 35.8). Genotypes 1 (76.9\%) and 3 (23.1\%) of HCV have been identified. A multivariate analysis demonstrated that HCV infection was independently associated with the following factors: "age ( $\geq 35$ years)", "tattoos", "use of a needle or syringe sterilized at home", "shared use of drug paraphernalia", "uses drugs for more than 5 years", and "use of drugs everyday".

Conclusions: This study revealed a high prevalence of HCV infection in non-injecting drug users, and most infections are occasioned by genotype 1. Likely, HCV transmission is associated with the tattoos, the use of needle or syringe sterilized at home by people over the age of 35 years, and sharing, time and frequency of use of non-injecting drugs. These findings should serve as an incentive for the establishment of a program of Hepatitis $C$ prevention and control by the local public-health authorities in order to develop effective policies and strategies for contain the spread of HCV infection.

Keywords: HCV, Epidemiology, Non-injecting drug, Public health, Amazon

\footnotetext{
* Correspondence: olivfilho@ufpa.br

${ }^{1}$ Instituto de Estudos Costeiros, Campus de Bragança, Universidade Federal

do Pará, Alameda Leandro Ribeiro, s/n. Aldeia, 68600-000 Bragança, Pará,

Brazil

${ }^{2}$ Centro de Hematologia e Hemoterapia do Pará, Belém, Pará, Brazil

Full list of author information is available at the end of the article
} 


\section{Background}

Currently, sharing of drug paraphernalia is the main form of transmission of the hepatitis $\mathrm{C}$ virus $(\mathrm{HCV})$ worldwide. It is estimated that more than $60 \%$ of the new cases of HCV infection recorded each year are related to the use of illicit drugs, especially by injection [1]. The prevalence of $\mathrm{HCV}$ infection in illicit drug users varies from $10 \%$ to $95 \%$, reflecting the presence or absence of specific risk factors, such as the history of drug use, sharing of drug paraphernalia (needles, syringes, pipes, cans, and so on), the number of partners present during shared use, detention and the use of drugs in jail or prison, and the type of consumption: inhaled or injected [2,3]. A number of studies have shown that the sharing of drug paraphernalia is responsible for the spread of HCV among both injecting drug users and non-injecting drug users $[2,4-6]$.

Recently in South America, consistent findings indicate that shared sniffing equipment is relevant in an important factor in the spread of HCV among noninjecting drug users [7-9]. In Brazil, epidemiological studies of $\mathrm{HCV}$ infection in non-injection drug user are still rare. There are few Brazilian studies investigating $\mathrm{HCV}$ infection in illicit drug users including both injecting and non-injecting drug users. Their $\mathrm{HCV}$ prevalence rates range from $5.8 \%$ to $36.2 \%$. HCV genotype 1 predominated, while genotype 3 was the second most common in illicit-drug users in Brazil [9-14].

Epidemiological data on the status of HCV infection in illicit-drug users in the Amazon are scarce, although reports of clinical cases of hepatitis or pathologies associated with $\mathrm{HCV}$ infection in other population groups are numerous [15-18]. The Amazon region is the site of most of the world production of cocaine and its derivatives [19]. Commonly, the police authorities record arrests and trafficking of cocaine and its derivatives in the Brazilian portion of the Amazon region (northern Brazil). Among the states that comprise the Brazilian Amazon, the state of Pará has become known for integrating various routes of trafficking cocaine and its derivatives in Brazil and around the world. Currently, most users of illicit drugs in Pará do not use injection as the route of administration, and are infected with HCV genotype $1[9,18]$. Research has suggested that $\mathrm{HCV}$ infection is highly prevalent in non-injecting cocaine users, and viral transmission is likely to be associated with "shared use of paraphernalia", "daily use of cocaine", and a "long history of cocaine use" [9]. Given this, the aim of this study was to estimate the prevalence of $\mathrm{HCV}$ infection and the main genotypes circulating among non-injecting drug users in the state of Pará, and to assess the factors associated with $\mathrm{HCV}$ infection in these subjects.

\section{Results}

In total, 327 illicit drug users agreed to participate in the study. However, twenty-seven patients had records of injection drug use and were excluded from analysis. According to information provided by 300 non-injecting drug users, this epidemiological study was developed. Most non-injecting drug users were male (63.7\%). The mean age was $32.5 \pm 10.3$ years (median $=31$ years). None of non-injecting drug users considered themselves to be ex-drug users (patients who reported that if they left drug-treatment centers (DTC) at the time of the interview, they would not resume using illicit drugs). Several participants $(49.1 \%)$ reported having consumed more than one illicit drug during their lifetime. Thus, illicit-drug users were grouped according to the drug used most frequently. Drug preference was grouped into seven categories: cannabis (15.6\%), cocaine paste (21.3\%), cannabis and cocaine paste $(11.7 \%)$, cocaine powder $(14.0 \%)$, cocaine powder and paste $(0.7 \%)$, oxi cocaine (25.7\%), and crack cocaine (11.0\%). Tobacco (60.9\%) and alcohol (79.4\%) were also commonly consumed by the subjects.

One hundred six (35.1\%; CI 95\%: 29.8 - 41.1) noninjecting drug users presented anti-HCV antibodies by EIA. Eighty-four (79.2\%) of these 106 had HCV-RNA detected by real-time PCR. The HCV-RNA prevalence among patients was $28.0 \%$ (95\% CI: 20.6 - 35.8). Furthermore, two hundred one (67.0\%; CI 95\%: 62.7 - 71.5) out of 300 non-injecting drug users were found by EIA to have anti-HIV antibodies. Sixty-three (31.3\%; CI 95\%: 26.2 - 36.2) of these 201 had anti-HCV antibodies detected by EIA, and forty-nine (24.4\%; CI 95\%: 18.7 - 29.9) had HCV-RNA detected by real-time PCR. The Table 1 shows more characteristics of the non-injecting drug users in this study. Using univariate analysis, several variables associated with $\mathrm{HCV}$ infection were identified: age ( $\geq 35$ years), surgery, tattoos, use of a needle or syringe sterilized at home, shared use of drug paraphernalia, history of illicit drug use, and frequency of illicit drug use (daily). However, the risk factors for $\mathrm{HCV}$ infection became clearer only after multiple logistic regression analysis. Risk factors for HCV infection among non-injecting drug users were: age ( $\geq 35$ years), tattoos, use of a needle or syringe sterilized at home, shared use of drug paraphernalia, history of illicit drug use (more than 5 years), and frequency of illicit drug use (daily) (Table 2). The Hosmer-Lemeshow goodness-of-fit test showed a good fit for the final model $1\left(_{\mathrm{HL}} X^{2}=4.4 ; \mathrm{p}=0.6\right)$ and model $2\left({ }_{\mathrm{HL}} X^{2}=3.1, \mathrm{p}=0.7\right)$.

A total of 84 nucleotide sequences of the 5' UTR of the HCV were isolated, of which $62(73.8 \%)$ were identical, so only one representative was maintained for the alignment. HCV genotypes were identified employing the model of Tamura-Nei adjusted by the parameters estimated through the PHYML program. The phylogenetic 
Table 1 Demographic and epidemiological characteristics of non-injecting drug users attending private and public drug-treatment centers located in the Brazilian state of Pará, eastern Amazon

\begin{tabular}{|c|c|c|c|c|c|}
\hline Characteristics & $\begin{array}{c}\text { Overall sample, } \\
N(\%)\end{array}$ & $\begin{array}{c}\text { Anti-HCV + } \\
n(\%)\end{array}$ & $\begin{array}{c}\text { OR } \\
\text { (Cl 95\%) } \\
\end{array}$ & $\begin{array}{c}\text { HCV-RNA + } \\
n(\%)\end{array}$ & $\begin{array}{c}\text { OR } \\
\text { (Cl 95\%) } \\
\end{array}$ \\
\hline Total & 300 & $106(35.3)$ & & $84(28.0)$ & \\
\hline Mean age (years) & 32.5 & 36.5 & & 37.3 & \\
\hline Age $\geq 35$ years & $114(38.0)$ & $63(59.4)$ & $4.1(2.5-6.8)$ & $44(52.4)$ & $2.3(1.4-3.8)$ \\
\hline Heterosexual & $279(93.0)$ & $101(95.3)$ & $1.7(0.6-4.9)$ & $78(92.9)$ & $1.0(0.4-2.6)$ \\
\hline Anti-HIV+ & $201(67.0)$ & $63(59.4)$ & $1.5(0.9-2.4)$ & $49(58.3)$ & $0.7(0.4-1.1)$ \\
\hline \multicolumn{6}{|l|}{ Supposed route of HCV infection } \\
\hline Family member or close friend infected with $\mathrm{HCV}$ & $23(7.7)$ & $5(4.7)$ & $0.5(0.2-1.3)$ & $3(3.5)$ & $0.4(0.1-1.2)$ \\
\hline Recipient of blood transfusion & $40(13.3)$ & $13(12.5)$ & $0.9(0.4-1.8)$ & $12(14.3)$ & $1.2(0.5-2.3)$ \\
\hline Surgery & $139(46.3)$ & $58(54.7)$ & $1.7(1.1-2.7)$ & $44(52.4)$ & $1.5(0.9-2.3)$ \\
\hline Tattoos & $177(59.0)$ & $81(76.4)$ & $3.3(1.9-5.6)$ & $76(90.5)$ & $10.9(5.0-23.7)$ \\
\hline Shared used of razor blades in the domestic environment & $102(34.0)$ & $40(37.7)$ & $1.3(0.8-2.1)$ & $33(39.3)$ & $1.4(0.8-2.3)$ \\
\hline Shared used of blades in a barbershop/beauty salon & $81(27.0)$ & $27(25.5)$ & $0.9(0.5-1.5)$ & $22(26.2)$ & $0.9(0.5-1.7)$ \\
\hline Use of a needle or syringe sterilized at home & $72(24.0)$ & $33(31.1)$ & $1.8(1.1-3.1)$ & $28(33.3)$ & $2.0(1.1-3.4)$ \\
\hline Shared nail clippers & $130(43.3)$ & $50(47.2)$ & $1.3(0.8-2.1)$ & $38(42.2)$ & $0.9(0.5-1.5)$ \\
\hline Invasive dental treatment & $227(75.7)$ & $81(76.4)$ & $1.1(0.6-1.9)$ & $65(77.4)$ & $1.1(0.6-2.1)$ \\
\hline Shared use of drug paraphernalia & $204(68.0)$ & $94(88.7)$ & $6.0(3.1-11.6)$ & $77(91.7)$ & $7.7(3.4-17.5)$ \\
\hline Use of drugs for more than 5 years & $199(66.3)$ & $88(83.0)$ & $3.7(2.0-6.5)$ & $69(82.1)$ & $3.1(1.6-5.7)$ \\
\hline Use of drugs everyday & $246(82.0)$ & $97(91.5)$ & $3.3(1.5-6.9)$ & $80(95.2)$ & $6.0(2.1-17.2)$ \\
\hline Have already been arrested in police station or prison & $84(28.0)$ & $28(33.3)$ & $0.9(0.5-1.4)$ & $20(23.8)$ & $0.7(0.4-1.3)$ \\
\hline Use of drugs during detention & $40(13.3)$ & $13(32.5)$ & $0.9(0.4-1.8)$ & $10(11.9)$ & $0.8(0.4-1.8)$ \\
\hline Unprotected sex & $234(78.0)$ & $79(74.5)$ & $0.7(0.4-1.3)$ & $63(75.0)$ & $0.8(0.4-1.4)$ \\
\hline Sexual intercourse with another drug user & $191(63.7)$ & $71(67.0)$ & $1.3(0.8-2.1)$ & $56(66.7)$ & $1.2(0.4-1.2)$ \\
\hline Involvement in prostitution & $157(52.3)$ & $50(47.2)$ & $0.7(0.5-1.2)$ & $36(42.9)$ & $0.7(0.4-1.2)$ \\
\hline More than 20 sexual partners over the past 2 years & $138(46.0)$ & $44(41.5)$ & $0.8(0.5-1.3)$ & $35(41.7)$ & $0.8(0.5-1.3)$ \\
\hline
\end{tabular}

tree revealed a marked prevalence of genotype 1 (76.9\%, 64/78), followed by genotype 3 (23.1\%, 20/78). Although, the bootstrap values were not significant $(<95.0)$, the phylogenetic tree indicated a predominance of subtype $1 \mathrm{~b}(50.0 \%, 42 / 84)$, followed by subtypes $1 \mathrm{a}$ $(26.2 \%, 22 / 84)$, 3a $(13.1 \%, 11 / 78)$, and 3b $(10.7 \%, 9 / 78)$ (Figure 1).

\section{Discussion}

In Latin America, the overall prevalence of $\mathrm{HCV}$ infection is about $1.23 \%$, however it varies from country to country [20,21]. In Brazil, the prevalence of HCV infection is around $1.38 \%$. In addition, significant differences in the prevalence of infection and distribution of $\mathrm{HCV}$ genotypes among Brazilian regions are reported. The

Table 2 Risk factors associated with HCV infection based on EIA (model 1) and PCR (model 2) results

\begin{tabular}{|c|c|c|c|c|}
\hline \multirow[t]{2}{*}{ Risk factors } & \multicolumn{2}{|c|}{ Model 1} & \multicolumn{2}{|c|}{ Model 2} \\
\hline & OR (Cl 95\%) & $p$-value & OR (Cl 95\%) & $p$-value \\
\hline Age ( $\geq 35$ years) & $2.3(1.1-3.9)$ & $<0.01$ & $2.1(1.2-4.4)$ & 0.02 \\
\hline Tattoos & $2.8(1.2-4.1)$ & $<0.01$ & $8.2(3.9-17.2)$ & $<0.01$ \\
\hline Use of a needle or syringe sterilized at home & $1.7(1.1-3.4)$ & 0.02 & $2.3(1.4-3.1)$ & $<0.01$ \\
\hline Shared use of drug paraphernalia & $5.6(1.8-9.5)$ & $<0.01$ & $4.1(1.9-8.4)$ & $<0.01$ \\
\hline Uses drugs for more than 5 years & $3.3(1.9-4.5)$ & $<0.01$ & $3.0(1.6-6.3)$ & $<0.01$ \\
\hline Use of drugs everyday & $2.5(1.4-3.7)$ & $<0.01$ & $3.8(1.1-6.5)$ & 0.01 \\
\hline
\end{tabular}




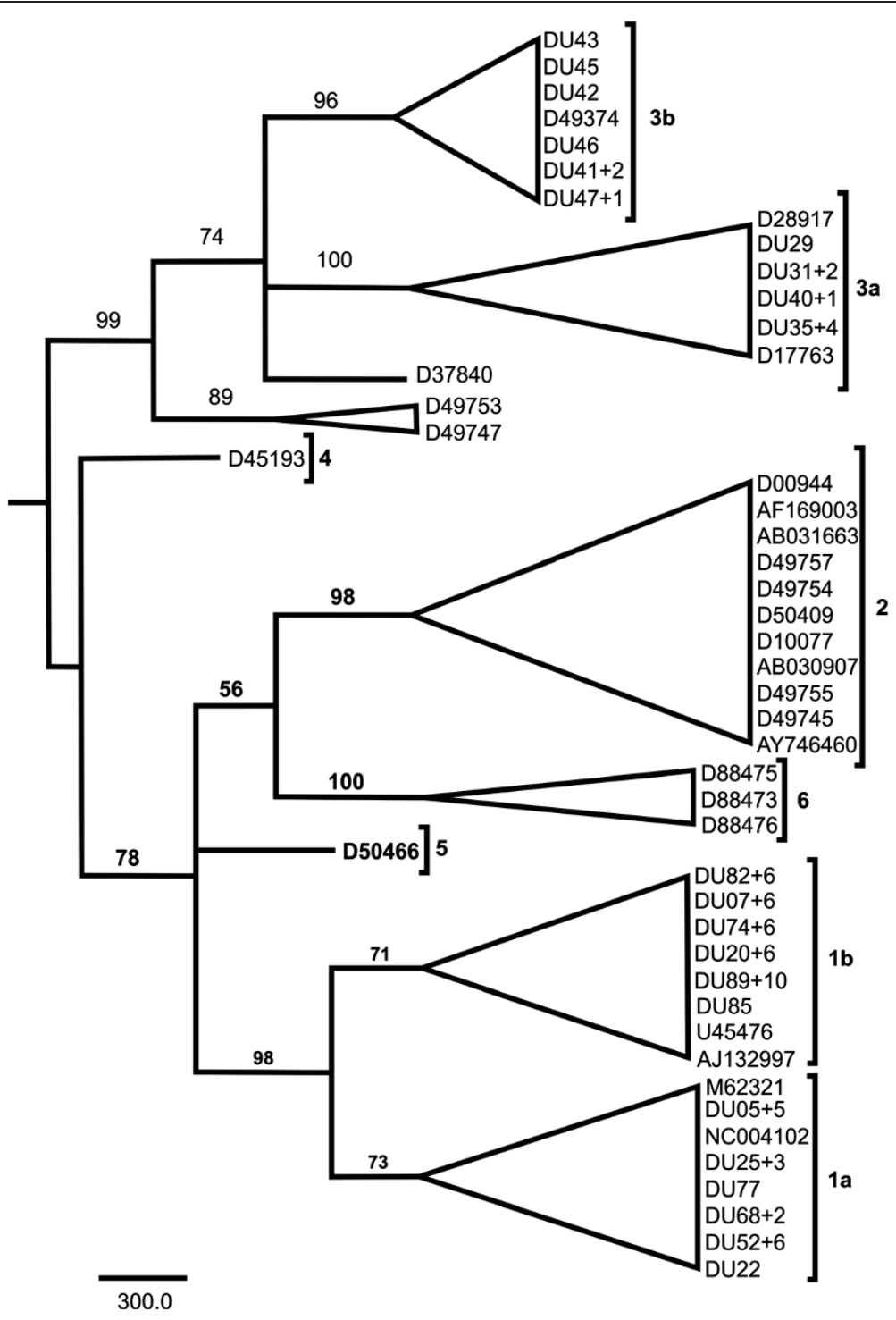

Figure 1 Maximum-likelihood phylogenetic tree derived from the alignment of 341 base pairs of the $5^{\prime}$ UTR of the Hepatitis C virus detected in non-injecting drug users in Pará, eastern Amazon. The topological robustness of the tree was evaluated using a bootstrap analysis with 1,000 replicates (bootstrap values of less than 50 are not shown). Drug users selected in this study can be identified by DU sample number (+ number of sequences representing).

northern of Brazil (Brazilian Amazon) stands out with the highest prevalence of infections and higher frequency of genotype $1[20,22,23]$. Among the risk groups for infection, illicit-drug users make up the main risk group for HCV infection in Brazil [20,22].

A consensus now exists that the use of non-injected drugs is a risk factor for the hepatitis $\mathrm{C}$ virus. Risk levels appear to vary substantially by location [5,6,24-26]. HCV prevalence in non-injecting drug users range from $2 \%$ to $38 \%$ in different parts of the world [3,8,11,27-29]. Epidemiological studies of illicit-drug users in the Northeast, Midwest, South and Southeast regions of Brazil (including both injecting and non-injecting drug users) have recorded prevalence of $\mathrm{HCV}$ infection between $5 \%$ and $36 \%$ [9-14]. The HCV prevalence recorded in the present study is within these estimated ranges, although the rate of $\mathrm{HCV}$ infection among non-injecting drug users in Pará was relatively high compared with the rates obtained in similar populations in different parts of the world, and extremely high and worrisome compared to the reported rates of $\mathrm{HCV}$ infection in other Brazilian regions. The marked prevalence of HCV-RNA in the drug-user population studied here should serve as an incentive for the establishment of a program of Hepatitis $C$ prevention and control by the local publichealth authorities. This program should include the use 
of non-injected drugs as a potential risk factor for transmission of HCV infection. Given the important consequence of this finding, more research on this topic is warranted in eastern Amazon.

The mechanisms of HCV transmission among noninjecting drug users are not well understood [3]. This study identified six risk factors for HCV infection. Having a tattoo was associated with HCV infection. Commonly, a tattoo is identified as a risk factor for $\mathrm{HCV}$ infection in illicit-drug users $[2,6,8]$. Likely, this reflects the lifestyle of illicit-drug users, which could include greater exposure to HCV. Furthermore, the daily use of drugs, paraphernalia sharing during drug use, and a long history of drug use were also associated with HCV infection in non-injecting drug users. Few studies have reported the presence of HCV-RNA in the nasal secretions of cocaine and crack users, indicating a possible alternative route for the transmission of the virus - the sharing of the paraphernalia used to consume these drugs $[4,30]$. One hypothesis to account for these cases involves intranasal transmission of $\mathrm{HCV}$ via contaminated implements, requiring two primary virological preconditions: the presence of blood and HCV in the nasal secretions of intranasal drug users, and the transfer of blood and HCV from the nasal cavity onto sniffing implements, which are often shared by intranasal drug users $[4,30]$. In Pará, HCV transmission may be associated with and powered by three risk factors: daily use of drugs, paraphernalia sharing during drug use, and a long history of drug use (more than 5 years). To prove this hypothesis, other, more-specific studies will be needed in the future.

Other risk factors for $\mathrm{HCV}$ infection identified in this study were age above 35 years, and use of a needle and glass syringe sterilized at home. Administering injectable medication without adequately sterilizing syringes or needles has been the main cause of HCV transmission worldwide, especially in developing countries $[1,31,32]$. In Brazil, disposable perforating and cutting materials for health procedures began to be used on a large scale during the second half of the 1980s. This situation, together with a lack of knowledge about HCV transmission, likely accounts for the higher prevalence of infection among Brazilians over 35, since transmission could have occurred through sharing of inadequately sterilized syringes and needles in homes with individuals who were asymptomatic and unaware that they were infected. Probably the risk factor "use of home-sterilized syringes and needles" was partly responsible for the significantly higher infection rate in the group older than 35 years. This may also indicate that longer exposure to risk factors increases the probability of infection with HCV. These two risk factors for $\mathrm{HCV}$ infection have also been detected in other Brazilian populations, including blood donors in the Brazilian state of Pará $[12,15,17,33]$.
In Brazil, $\mathrm{HCV}$ genotype 1 predominates, followed by genotypes 3 and 2 [23,34]. In the Brazilian Amazon, HCV genotype 1 prevails in blood donors, health-care workers, illicit-drug users, patients with chronic hematological disease, and patients undergoing hemodialysis $[12,15,17,18]$. The results of the present study were well within this range, with a high frequency of $\mathrm{HCV}$ genotype 1 (1a and $1 \mathrm{~b})$ and the presence of genotype 3 ( $3 \mathrm{a}$ and $3 \mathrm{~b}$ ). This study also showed that in a geographic area in which the populations are predominantly infected with genotype 1 , a relatively high frequency of genotype 3 can also occur $[15-17,34]$. This study concords with the finding of several other studies that reported the existence of a significant frequency of genotype 3 in illicit-drug users, reflecting the intrinsic characteristic of network transmission through sharing of illicit drugs and abuse of their paraphernalia $[11,12,18,35,36]$.

The present study has limitations that should be considered in the interpretation of results. No procedures for identifying injection drug use, including those used in this study, are foolproof. The number of non-injecting drug users and their general characteristics in the state of Pará are not actually known since drug use is an illicit activity. For that reason, HCV infection was only investigated among those non-injecting drug users enrolled in private and public drug treatment centers during the study period. On the other hand, given the scarcity of epidemiological data about HCV infection among illicit-drug users in the state do Pará, our results provide background information for formulating policies and strategies for reducing risk and damage associated to the use of illicit drugs. Furthermore, the specific sexual behavior of illicit-drug users in detention was not investigated. Some studies suggest that illicit-drug use and sexual behavior during detention may be associated with $\mathrm{HCV}$ infection $[28,37]$. Finally, the 5 ' UTR contains sufficient variation to resolve HCV classifications at the level of viral genotype. However, it is conserved and limited in its ability to discriminate subtypes within genotypes $1,2,3,4$, and 6 [38]. Thus, there is a need for sequencing of other regions of the $\mathrm{HCV}$ genome to improve the resolution of viral subtypes.

\section{Conclusions}

This study revealed a high prevalence of HCV infection in non-injecting drug users. Genotype 1 has the highest frequency, and also detected the genotype 3. Likely viral transmission occurred by three mechanisms: (1) tattoos, (2) sharing needles and glass syringes at home associated with age over 35 years, and (3) a combination of shared use of paraphernalia, daily use, and a long history of non-injection drug use. These factors require special attention from public-health authorities in the Amazon region, in order to develop effective policies and strategies 
for contain the spread of HCV infection in the population of non-injecting drug users.

\section{Methods}

\section{Sample collection}

This was a cross-sectional study conducted in private and public DTC in nine municipalities in the Brazilian state of Pará (Abaetetuba, Ananindeua, Belém, Benevides, Bragança, Castanhal, Marituba, São Francisco do Pará, and Vigia), eastern Amazon. Twenty-five (78.1\%) of the 32 DTC that existed during the study period collaborated with the research. These included DTC located within $350 \mathrm{~km}$ by road from the Centro de Hematologia e Hemoterapia do Pará (HEMOPA), Belém, PA, Brazil. Each DTC was visited at a time scheduled by the research team. The DTC had an average capacity of 15 patients. All patients who were at the center on the day when the team visited participated voluntarily. This study included participants who were using only non-injectable drugs, and excluded participants aged below 18 years. All data were collected from February 2008 to January 2011. The study was approved by the Research and Ethics Committee of the Núcleo de Medicina Tropical of the Universidade Federal do Pará, Brazil.

\section{Testing}

Blood (5 ml) was collected in sterile tubes, allowed to clot, and centrifuged at room temperature. The resulting plasma samples were collected and stored at a temperature below $10^{\circ} \mathrm{C}$. After the end of the collection period at each DTC, the samples were transported to HEMOPA. The plasma was then tested for the presence of anti-HCV antibodies by enzyme immunoassay (EIA). The Murex anti-HCV version 4.0 (Kyalami, Gauteng, South Africa) was used to measure anti-HCV antibody levels. Nonreactive samples were considered negative for HCV. Reactive sample by EIA were submitted to RNA extraction, reverse transcription, and real-time PCR with primers complementary to the conserved area of the 5' UTR of HCV, as described elsewhere [17]. Furthermore, the HIV/HCV co-infection was evaluated. All plasma collected was tested for HIV antibody by EIA. The Murex HIV-1.2.O (Saluggia, Vercelli, Italy) was used to measure anti-HIV antibodies. All tests for diagnosis of viral infections were performed at the Laboratory of Cellular and Molecular Biology of the HEMOPA.

\section{Genotyping}

Following the molecular screening for $\mathrm{HCV}$ infection using real-time PCR, samples that were positive for HCV-RNA were selected for the amplification of 5' UTR using nested PCR [39]. The amplified fragment was sequenced in both directions using a Big Dye Cycle Sequencing standard kit and the dideoxynucleotide chain terminator method in an ABI Prism 3130 system (Applied Biosystems - Foster City, California, USA). All the nucleotide sequences obtained were edited and aligned using the BioEdit program [40]. The final alignment was entered into the DnaSP program [41] for the identification of identical nucleotide sequences. Nucleotide sequences obtained from the NCBI were added to the alignment and used for the construction of the phylogenetic tree and the differentiation of the HCV genotypes, as described elsewhere [18]. Nucleotide sequence data obtained in this study are available in GenBank under the accession numbers JN243906-JN243997.

\section{Questionnaire and records}

The identification of the factors associated with $\mathrm{HCV}$ infection was based on the use of structured questionnaire (face-to-face interviews), in which the following variables were determined: gender, age, close family or friends with hepatitis $C$, recipient of blood transfusion, had surgery during the subject's lifetime, had invasive dental treatment (root canal or tartar removal) during the subject's lifetime, tattoo, shared used of razor blades in the domestic environment, shared used of blades in a barbershop, beauty salon or similar environment, use of a needle or syringe sterilized at home, shared nail clippers, types of legal drugs used during the subject's lifetime, total time of drug use, frequency of drug use, shared use of drug paraphernalia (tubes, cans, pipes and similar), have already been arrested in police station or prison, use of drugs during detention in jails or prison, sexual orientation, unprotected sex, sexual intercourse with another drug user, involvement in prostitution, and multiple sexual partners. Furthermore, DTC structured admission records were reviewed to assess drug-use histories. The records include data on drug preference, length of drug use, sexual risk behavior, the main drugs used and their routes of administration. When clients enter treatment, each major part of the body - head, trunk, extremities and so on is examined. If needle use indications are identified, they are recorded in the client's records. The information provided by participants through the questionnaire was compared with the records stored in DTC to identify and delete injecting drug users.

\section{Statistical analysis}

Wilson confidence intervals were constructed for the infection prevalence estimates [42]. Simple and multiple logistic regressions were done to assess the independent effect of variables [33]. The fit of the final model was assessed using the Hosmer-Lemeshow goodness-of-fit test. Two definitions of $\mathrm{HCV}$ infection cases were used: (i) anti-HCV positivity shown by EIA, and (ii) HCVRNA detection by real-time PCR. All statistical analyses were carried out using PASW Statistics version 18.0. 


\section{Competing interests}

The authors declare that they have no competing interests.

\section{Authors' contributions}

All authors contributed to the development of research. Study design: ABOF, JARL. Data collection and laboratory techniques: ABOF, LS, LCP, DL, SLB, JAAC, RBH, IBC, CEMA, JARL. Statistical analysis: ABOF, LS, LCP, SLB, JAAC, $\mathrm{RBHH}, \mathrm{IBC}, \mathrm{CEMA}$. Phylogenetic analysis: ABOF, LS, DL. Writing of the manuscript: ABOF. Reviewing the manuscript: $L S, L C P, S L B, D L, J A A C, R B H$, IBC, CEMA, JARL. All authors read and approved the final manuscript.

\section{Acknowledgements}

This study was supported by CNPQ, MS/SVS, PROPESP/UFPA and FADESP. A. B. Oliveira-Filho received scholarship from CNPQ for the development of this research.

\section{Author details}

${ }^{1}$ Instituto de Estudos Costeiros, Campus de Bragança, Universidade Federal do Pará, Alameda Leandro Ribeiro, s/n. Aldeia, 68600-000 Bragança, Pará, Brazil. ${ }^{2}$ Centro de Hematologia e Hemoterapia do Pará, Belém, Pará, Brazil. ${ }^{3}$ Chiba Institute of Technology, Tsudanuma, Narashino-shi, Chiba, Japan. ${ }^{4}$ Instituto de Ciências Biológicas, Universidade Federal do Pará, Belém, Pará, Brazil. ${ }^{5}$ Instituto Evandro Chagas, Ananindeua, Pará, Brazil.

Received: 9 January 2014 Accepted: 18 February 2014 Published: 25 February 2014

\section{References}

1. Alter MJ: Epidemiology of hepatitis C virus infection. World J Gastroenterol 2007, 13(17):2436-2441.

2. Aceijas C, Rhodes T: Global estimates of prevalence of HCV infection among injecting drug users. Int J Drug Policy 2007, 18(5):352-358.

3. Scheinmann R, Hagan H, Lelutiu-Weinberger C, Stern R, Des Jarlais DC, Flom PL, Strauss S: Non-injection drug use and hepatitis $C$ virus: a systematic review. Drug Alcohol Depend 2007, 89(1):1-12

4. Aaron S, McMahon JM, Milano D, Torres L, Clatts M, Tortu S, Mildvan D, Simm M: Intranasal transmission of hepatitis $C$ virus: virological and clinical evidence. Clin Infect Dis 2008, 47(7):931-934.

5. Macías J, Palacios RB, Claro E, Vargas J, Vergara S, Mira JA, Merchante N, Corzo JE, Pineda JA: High prevalence of hepatitis $C$ virus infection among noninjecting drug users: association with sharing the inhalation implements of crack. Liver Int 2008, 28(6):781-786.

6. Allison RD, Conry-Cantilena C, Koziol D, Schechterly C, Ness P, Gibble J, Kleiner DE, Ghany MG, Alter HJ: A 25-year study of the clinical and histologic outcomes of hepatitis $C$ virus infection and its modes of transmission in a cohort of initially asymptomatic blood donors. J Infect Dis 2012, 206(5):654-661.

7. Caiaffa WT, Rossi D: Hepatites virais e vulnerabilidade em usuários de cocaína na América do Sul. Cad Saúde Pública 2011, 27(9):1664-1665.

8. Caiaffa WT, Zocratto KF, Osimani ML, Martínez PL, Radulich G, Latorre L, Muzzio E, Segura M, Chiparelli H, Russi J, Rey J, Vazquez E, Cuchi P, Sosa-Estani S, Rossi D, Weissenbacher M: Hepatitis C virus among non-injecting cocaine users (NICUs) in South America: can injectors be a bridge? Addiction 2011, 106(1):143-151.

9. Oliveira-Filho AB, Sawada L, Pinto LC, Locks D, Bahia SL, Brasil-Costa I, Lemos JAR: HCV infection among cocaine users in the state of Pará, Brazilian Amazon. Arch Virol 2013, 158(7):1555-1560.

10. Oliveira ML, Hacker MA, Oliveira SA, Telles PROKM, Yoshida CF, Bastos FI: "The first shot": the context of first injection of illicit drugs, ongoing injecting practices, and hepatitis $C$ infection in Rio de Janeiro, Brazil. Cad Saúde Pública 2006, 22(4):861-870.

11. Lopes CL, Teles SA, Espírito-Santo MP, Lampe E, Rodrigues FP, Motta-Castro AR, Marinho TA, Reis NR, Silva AM, Martins RM: Prevalence, risk factors and genotypes of hepatitis $C$ virus infection among drug users, Central-Western Brazil. Rev Saude Publica 2009, 43(Suppl 1):43-50.

12. Novais AC, Lopes CL, Reis NR, Silva AM, Martins RM, Souto FJ: Prevalence of hepatitis $C$ virus infection and associated factors among male illicit drug users in Cuiabá, Mato Grosso, Brazil. Mem Inst Oswaldo Cruz 2009, 104(6):892-896.

13. Oliveira ML, Yoshida CF, Telles PR, Hacker MA, Oliveira SA, Miguel JC, Do OKM, Bastos Fl: Trends in HCV prevalence, risk factors and distribution of viral genotypes in injecting drug users: findings from two cross-sectional studies. Epidemiol Infect 2009, 137(7):970-979.

14. Silva MB, Andrade TM, Silva LK, Rodart IF, Lopes GB, Carmo TM, Zarife MA, Dourado I, Reis MG: Prevalence and genotypes of hepatitis $C$ virus among injecting drug users from Salvador-BA, Brazil. Mem Inst Oswaldo Cruz 2010, 105(3):299-303.

15. Paraná R, Paiva T, Leite MR, Oliveira FN, Kali N, Lobato C, Dantas T, Neto JT: Infection with hepatitis $C$ virus among health care workers in the Brazilian Western Amazon Region (Rio Branco, state of Acre). Am J Trop Med Hyg 2007, 76(1):165-169.

16. Torres KL, Malheiro A, Tateno A, De-Lima TA, Viana-Maia LP, Diniz-Pimentel JP, Encarnação-de-Morais MP, De-Melo-Usui CS, De-Oliveira-Braga F, Ferreira-Silva IA, Vasquez F, Eduardo-Levi J: Hepatitis C virus in blood donors, Brazil. Emerg Infect Dis 2009, 15(4):676-678.

17. Oliveira-Filho AB, Pimenta AS, Rojas MF, Chagas MC, Crescente JA, Crespo DM, Lemos JA: Prevalence and genotyping of hepatitis $c$ virus in blood donors in the state of Pará, Northern Brazil. Mem Inst Oswaldo Cruz 2010, 105(1):103-106.

18. Sawada L, Pinheiro AC, Locks D, Pimenta Ado S, Rezende PR, Crespo DM, Crescente JÂ, Lemos JA, Oliveira Filho AB: Distribution of HCV genotypes among different exposure categories in the State of Pará, Brazilian Amazon. Rev Soc Bras Med Trop 2011, 44(1):8-12.

19. United Nations Office on Drugs and Crime: World Drug Report. 2012. http://www.unodc.org/unodc/en/data-and-analysis/WDR-2012.html.

20. Méndez-Sánchez N, Gutiérrez-Grobe Y, Kobashi-Margáin RA: Epidemiology of HCV infection in Latin America. Ann Hepatol 2010, 9(Suppl. 1):S27-S29.

21. Te HS, Jensen DM: Epidemiology of hepatitis $B$ and $C$ viruses: a global overview. Clin Liver Dis 2010, 14(1):1-21

22. Pereira LMMB, MArtelli CMT, Moreira RC, Merchan-Hamman E, Stein AT, Cardoso MRA, Figueiredo GM, Montarroyos UR, Braga C, Turchi MD, Coral G, Crespo D, Lima MLC, Alencar LCA, Costa M, Santos AA, Ximenes RAA: Prevalence and risk factors of hepatitis $C$ virus infection in Brazil, 2005 through 2009: a cross-sectional study. BMC Infect Dis 2013, 13:60.

23. Martins T, Narciso-Schiavon JL, Schiavon LL: Epidemiology of hepatitis $C$ virus infection. Rev Assoc Med Bras 2011, 57(1):107-112.

24. Wang CC, Krantz E, Klarquist J, Krows M, McBride L, Scott EP, Shaw-Stiffel T, Weston SJ, Thiede H, Wald A, Rosen HR: Acute hepatitis C in a contemporary US cohort: modes of acquisition and factors influencing viral clearance. $J$ Infect Dis 2007, 196(10):1474-1482.

25. Martinez A, Talal AH: Non-injection drug use: an under-appreciated risk factor for hepatitis C virus transmission. Liver Int 2008, 28(6):757-760.

26. Van den Berg CH, van de Laar TJ, Kok A, Zuure FR, Coutinho RA, Prins M: Never injected, but hepatitis $C$ virus-infected: a study among self-declared never-injecting drug users from the Amsterdam cohort studies. J Viral Hepat 2009, 16(8):568-577.

27. Xia X, Luo J, Bai J, Yu R: Epidemiology of hepatitis C virus infection among injection drug users in China: systematic review and meta-analysis. Public Health 2008, 122(10):990-1003.

28. Campollo O, Roman S, Panduro A, Hernandez G, Diaz-Barriga L, Balanzario MC, Cunningham JK: Non-injection drug use and hepatitis $C$ among drug treatment clients in west central Mexico. Drug Alcohol Depend 2012, 123(1-3):269-272

29. Galperim B, Cheinquer $H$, Stein A, Fonseca A, Lunge V, Ikuta N: Intranasal cocaine use does not appear to be an independent risk factor for HCV infection. Addiction 2004, 99(8):973-977.

30. Fischer B, Powis J, Firestone Cruz M, Rudzinski K, Rehm J: Hepatitis C virus transmission among oral crack users: viral detection on crack paraphernalia. Eur J Gastroenterol Hepatol 2008, 20(1):29-32.

31. Simonsen L, Kane A, Lloyd J, Zaffran M, Kane M: Unsafe injections in the developing world and transmission of bloodborne pathogens: a review. Bull World Health Organ 1999, 77(10):789-800.

32. Reeler AV: Injections: a fatal attraction. Soc Sci Med 1990, 31(10):1119-1125.

33. Oliveira-Filho AB, Pimenta Ado S, Rojas Mde F, Chagas MC, Crespo DM, Crescente JA, Lemos JA: Likely transmission of hepatitis $C$ virus through sharing of cutting and perforating instruments in blood donors in the State of Pará, Northern Brazil. Cad Saúde Pública 2010, 26(4):837-844.

34. Campiotto S, Pinho JR, Carrilho FJ, Da Silva LC, Souto FJ, Spinelli V, Pereira LM, Coelho HS, Silva AO, Fonseca JC, Rosa H, Lacet CM, Bernardini AP: Geographic distribution of hepatitis $C$ virus genotypes $C$ in Brazil. Braz J Med Biol Res 2005, 38(1):41-49. 
35. Morice $Y$, Cantaloube JF, Beaucourt S, Barbotte L, De Gendt S, Goncales FL, Butterworth L, Cooksley G, Gish RG, Beaugrand M, Fay F, Fay O, Gonzalez JE, Martins RM, Dhumeaux D, Vanderborght B, Stuyver L, Sablon E, de Lamballerie X, Pawlotsky JM: Molecular epidemiology of hepatitis C virus subtype 3a in injecting drug users. J Med Virol 2006, 78(10):1296-1303.

36. Zhou DX, Tang JW, Chu IM, Cheung JL, Tang NL, Tam JS, Chan PK: Hepatitis $C$ virus genotype distribution among intravenous drug user and the general population in Hong Kong. J Med Virol 2006, 78(5):574-581.

37. Fox RK, Currie SL, Evans J, Wright TL, Tobler L, Phelps B, Busch MP, Page-Shafer KA: Hepatitis $C$ virus infection among prisoners in the California state correctional system. Clin Infect Dis 2005, 41(2):177-186.

38. Hraber PT, Fischer W, Bruno WJ, Leitner T, Kuiken C: Comparative analysis of hepatitis $C$ virus phylogenies from coding and non-coding regions: the 5' untranslated region (UTR) fails to classify subtypes. Virol J 2006, 3:103.

39. Oliveira-Filho AB, Oliveira EH, Castro JA, Silva LV, Vallinoto AC, Lemos JA Epidemiological aspects of $\mathrm{HCV}$ infection in HIV-infected individuals in Piauí State, Northeast Brazil. Arch Virol 2012, 157(12):2411-2416.

40. Hall T: BioEdit: a user-friendly biological sequence alignment editor and analysis program for Windows 95/98/NT. Nucleic Acids Symp Ser 1999, 41:95-98.

41. Librado P, Rozas J: DnaSP v5: software for comprehensive analysis of DNA polymorphism data. Bioinformatics 2009, 25(11):1451-1452.

42. Brown LD, Cai TT, DasGupta A: Interval estimation for a binominal proportion. Statist Sci 2001, 16(2):101-133.

doi:10.1186/1743-422X-11-38

Cite this article as: Oliveira-Filho et al:: Epidemiological aspects of HCV infection in non-injecting drug users in the Brazilian state of Pará, eastern Amazon. Virology Journal 2014 11:38.

\section{Submit your next manuscript to BioMed Central and take full advantage of:}

- Convenient online submission

- Thorough peer review

- No space constraints or color figure charges

- Immediate publication on acceptance

- Inclusion in PubMed, CAS, Scopus and Google Scholar

- Research which is freely available for redistribution 